\title{
Protocol of the Court of Justice of the African Union
}

The Member States of the African Union:

Considering that the Constitutive Act established the Court of Justice of the African Union;

Firmly convinced that the attainment of the objectives of the African Union requires the establishment of the Court of Justice of the African Union;

HAVE AGREED AS FOLLOWS:

\section{CHAPTER I}

\section{Article 1: DEFINITIONS}

In this Protocol unless otherwise specifically stated:

"Act" means the Constitutive Act of the Union;

"Assembly" means the Assembly of Heads of State and Government of the Union;

"Commission" means the Commission of the Union;

"Court" means the Court of Justice of the Union;

"ECOSOCC" means the Economic, Social and Cultural Council of the Union;

"Executive Council" means the Executive Council of Ministers of the Union;

"Financial Institutions" means the Financial Institutions established by the Constitutive Act;

"Judge" means a judge of the Court;

"Member State" means a Member State of the Union;

"Parliament" means the Pan-African Parliament of the Union;

"Peace and Security Council" means the Peace and Security Council of the Union;

"President" means the President of the Court;

"Protocol" means this Protocol defining the composition, powers and functions of the Court;

"Regions" means the geographical regions into which the continent of Africa, at any time, is divided pursuant to a decision of the Assembly; 
"Rules of Court" means the Rules of Court under Article 58;

"Registrar" means the Registrar of the Court;

"States Parties" means the Member States that have ratified or acceded to this Protocol;

"Union" means the African Union established by the Act;

"Vice President" means the Vice President of the Court;

\section{Article 2: ESTABLISHMENT OF THE COURT}

1. The Court established by the Act shall function in accordance with the provisions of the Act and this Protocol.

2. The Court shall be the principal judicial organ of the Union.

\section{Article 3: COMPOSITION}

1. The Court shall consist of eleven (11) Judges who are nationals of States Parties.

2. The Assembly may, when it deems it necessary, review the number of Judges.

3. The Judges shall be assisted by the necessary staff for the smooth functioning of the Court.

4. No two (2) Judges shall be nationals of the same State Party.

5. In the Court as a whole, the representation of the principal legal traditions of Africa shall be assured.

6. Each region shall be represented by no less than two (2) Judges.

\section{CHAPTER II}

\section{Article 4: QUALIFICATIONS}

The Court shall be composed of impartial and independent Judges elected from among persons of high moral character, who possess the necessary qualifications required in their respective countries for appointment to the highest judicial offices, or are jurists of recognized competence in international law.

\section{Article 5: SUBMISSION OF CANDIDATES}

1. Upon entry into force of this Protocol, the Chairperson of the Commission shall request each State Party to submit in writing within ninety (90) days of such a request, its nomination for the office of a Judge of the Court.

2. Each State Party may nominate only one (1) candidate having the qualifications prescribed in Article 4 of this Protocol. 
3. Due consideration shall be given to adequate gender representation in the nomination process.

\section{Article 6: LIST OF CANDIDATES}

The Chairperson of the Commission shall prepare a list of the candidates nominated, in alphabetical order and transmit it to the Member States at least thirty (30) days prior to the ordinary session of the Assembly at which the Judges are to be elected.

\section{Article 7: ELECTION OF JUDGES OF THE COURT}

1. The Assembly shall elect the Judges by secret ballot and by two- thirds majority of the Member States eligible to vote.

2. Where one or more candidates fail to obtain the two-thirds majority required for an election, the balloting shall continue until the required number of Judges has been elected. However, the next ballots shall be restricted to the candidates who obtain the greatest number of votes.

3. In the election of the Judges, the Assembly shall ensure that there is equal gender representation.

\section{Article 8: TENURE OF OFFICE}

1. The Judges shall be elected for a period of six (6) years and may be re-elected only once. The term of five (5) Judges elected at the first election shall expire at the end of four (4) years and the other Judges shall serve the full term.

2. The Judges whose terms are to expire at the end of the initial period of four (4) years shall be chosen by lot to be drawn by the Chairperson of the Assembly immediately after the first election has been completed.

3. A Judge elected to replace another Judge whose term of office has not expired shall be from the same region and shall hold office for the remainder of the predecessor's term.

\section{Article 9: OATH OF OFFICE}

1. Before taking up his or her duties each Judge shall in open court take the following oath:

“I

Do solemnly swear (or affirm or declare) that I shall faithfully exercise the duties of my office as Judge of the Court of Justice of the African Union impartially and conscientiously, without fear or favour, affection or illwill and that I will preserve the secrecy of the deliberations of the Court."

2. The oath of office shall be administered by the Chairperson of the Assembly or his or her duly authorized representative. 


\section{Article 10: PRESIDENCY OF THE COURT}

1. The Court shall elect its President and Vice -President for a period of three (3) years. The President and Vice-President may be re-elected once.

2. The President shall reside at the seat of the Court.

3. The modalities for elections of the President and the Vice-President and their functions shall be set out in the Rules of Court.

\section{Article 11: RESIGNATION, SUSPENSION AND REMOVAL FROM OFFICE}

1. A Judge may resign his or her position in writing addressed to the President for transmission to the Chairperson of the Assembly.

2. A Judge shall not be suspended or removed from office save where, on the unanimous recommendation of the other Judges, he or she no longer fulfils the requisite conditions to be a Judge.

3. The President shall communicate the recommendation for the suspension or removal of a judge to the Chairperson of the Assembly and the Chairperson of the Commission.

4. Such a recommendation of the Court shall become final upon its adoption by the Assembly.

\section{Article 12: VACANCIES}

1. A vacancy shall arise in the Court under the following circumstances:

a death;

b resignation;

c removal from office.

2. In the case of death or resignation of a Judge, the President shall immediately inform the Chairperson of the Assembly in writing, who shall declare the seat vacant.

3. The same procedure and consideration for the election of a Judge shall also be followed in filling vacancies.

\section{Article 13: INDEPENDENCE}

1. The independence of the Judges shall be fully ensured in accordance with international law.

2. No Judge may participate in the decision of any case in which he or she has previously taken part as agent, counsel or advocate for one of the parties, or as a member of a national or international court, or commission of inquiry, or in any other capacity.

3. Any doubt on this point shall be settled by decision of the Court. 


\section{Article 14: PRIVILEGES AND IMMUNITIES}

1. The Judges shall enjoy, from the time of their election and throughout their term of office, the full privileges and immunities extended to diplomatic agents in accordance with international law.

2. The Judges shall be immune from legal proceedings for any act or omission committed in the discharge of their judicial functions.

3. The Judges shall continue, after they have ceased to hold office, to enjoy immunity in respect of acts performed by them when engaged in their official capacity.

\section{Article 15: INCOMPATIBILITY}

1. The position of a Judge shall be incompatible with any activity that might interfere with the independence or impartiality of such a judge or the demands of the office, as determined in the Rules of Court.

2. Any doubt on this point shall be settled by the Court.

\section{Article 16: QUORUM}

1. The full Court shall sit except where it is expressly provided otherwise in this Protocol;

2. Except when sitting in Chamber, the Court shall only examine cases brought before it, if it has a quorum of at least seven (7) Judges;

3. The quorum for a Special Chamber shall be set out in the Rules of Court.

\section{Article 17: REMUNERATION OF JUDGES}

1. A Judge shall receive an annual allowance and, for each day on which he or she exercises his or her functions, a special allowance, provided that in any year the total sum payable to any Judge as special allowance shall not exceed the amount of the annual allowance.

2. The President shall receive an additional special annual allowance.

3. The Vice-President shall receive an additional special allowance for each day on which he or she acts as President.

4. The allowances shall be determined from time to time by the Assembly upon the recommendation of the Executive Council, taking into account the workload of the Court. They may not be decreased during the term of office.

5. Regulations adopted by the Assembly upon the recommendation of the Executive Council shall determine the conditions under which retirement pensions shall be given to the Judges and the terms and conditions under which their travel expenses shall be paid or refunded. 
6. The allowances shall be free of all taxation.

\section{Article 18: ELIGIBILITY TO SUBMIT CASES}

1. The following are entitled to submit cases to the Court:

a States Parties to this Protocol;

b The Assembly, the Parliament and other organs of the Union authorised by the Assembly;

c The Commission or a member of staff of the Commission in a dispute between them within the limits and under the conditions laid down in the Staff Rules and Regulations of the Union;

d Third Parties under conditions to be determined by the Assembly and with the consent of the State Party concerned.

2. The conditions under which the Court shall be open to third parties shall, subject to the special provisions contained in treaties in force, be laid down by the Assembly, but in no case shall such conditions place the parties in a position of inequality before the Court.

3. The States which are not members of the Union shall not be allowed to submit cases to the Court. The Court shall have no jurisdiction to deal with a dispute involving a Member State that has not ratified this Protocol.

\section{Article 19: COMPETENCE/JURISDICTION}

1. The Court shall have jurisdiction over all disputes and applications referred to it in accordance with the Act and this Protocol which relate to:

a the interpretation and application of the Act;

b the interpretation, application or validity of Union treaties and all subsidiary legal instruments adopted within the framework of the Union;

c any question of international law;

d all acts, decisions, regulations and directives of the organs of the Union;

e all matters specifically provided for in any other agreements that States Parties may conclude among themselves or with the Union and which confer jurisdiction on the Court;

f the existence of any fact which, if established, would constitute a breach of an obligation owed to a State Party or to the Union;

$\mathrm{g}$ the nature or extent of the reparation to be made for the breach of an obligation.

2. The Assembly may confer on the Court power to assume jurisdiction over any dispute other than those referred to in this Article.

\section{CHAPTER III}

\section{Article 20: SOURCES OF LAW}

1. The Court, whose function is to decide in accordance with international law such disputes, as are submitted to it, shall have regard to: 
a

b International treaties whether general or particular, establishing rules expressly recognized by the contesting states;

c International custom, as evidence of a general practice accepted as law;

d The general principles of law recognized universally or by African States;

e Subject to Article 37 of this Protocol, judicial decisions and the writings of the most highly qualified publicists of various nations as well as the regulations, directives and decisions of the Union as subsidiary means for the determination of the rules of law.

2. This provision shall not prejudice the power of the Court to decide a case ex aequo et bono, if the parties, agree thereto.

\section{CHAPTER IV}

\section{Article 21: SUBMISSION OF A DISPUTE}

1. Disputes shall be submitted to the Court by a written application to the Registrar. The subject of the dispute, the applicable law and basis of the jurisdiction shall be indicated.

2. The Registrar shall forthwith give notice of the application to all concerned parties.

3. The Registrar shall also notify all Member States, the Chairperson of the Commission and any third parties entitled to appe ar before the Court.

\section{Article 22: PROVISIONAL MEASURES}

1. The Court shall have the power, on its own motion or on application by the parties, to indicate, if it considers that circumstances so require any provisional measures which ought to be taken to prese rve the respective rights of the parties.

2. Pending the final decision, notice of the provisional measures shall forthwith be given to the parties and to the Chairperson of the Commission.

\section{Article 23: REPRESENTATION OF PARTIES}

1. The parties may be represented before the Court by agents.

2. An agent or party may have the assistance of counsel or advocate before the Court.

3. The organs of the Union, where relevant, shall be represented by the Chairperson of the Commission or his or her representative.

4. The agents, counsel and advocates of the parties before the Court shall enjoy the privileges and immunities necessary to the independent exercise of their duties. 


\section{Article 24: PROCEDURE BEFORE THE COURT}

1. The procedure before the Court shall consist of two parts: written and oral.

2. The written procedure shall consist of the communications to the Court, the parties and the institutions of the Union whose decisions are in dispute, of applications, statements of the case, defences and observations and of replies if any, as well as all papers and documents in support, or of certified copies thereof.

3. The communications shall be made through the Registrar, in the order and time fixed by the Court either in the Rules or the case.

4. A certified copy of every document produced by one party shall be communicated to the other party.

5. The oral proceedings shall, if necessary, consist of hearing by the Court of witnesses, experts, agents, counsels and advocates.

\section{Article 25: SERVICE OF NOTICE}

1. For the service of all notices upon persons other than parties, agents, counsel and advocates, the Court shall apply direct to the government of the State upon whose territory the notice has to be served.

2. The same provision shall apply whenever steps are to be taken to procure evidence locally in the territory of the State concerned.

\section{Article 26: PUBLIC HEARING}

The hearing in Court shall be public, unless the Court, on its own motion or upon application by the parties, decides that the public not be admitted.

\section{Article 27: RECORD OF PROCEEDINGS}

1. A record of proceedings shall be made at each hearing and shall be signed by the presiding Judge and the Registrar of the session.

2. Such a record shall be kept by the Registrar and shall be the authentic record of the case.

\section{Article 28: REGULATION OF PROCEEDINGS}

1. The Court shall have the power to regulate its own proceedings. It shall have the power to make orders for the conduct of the case before it.

2. It shall decide the form and time in which each party must conclude its arguments, and make all arrangements connected with the taking of evidence.

\section{Article 29: PRODUCTION OF DOCUMENTS}

The Court may, before the hearing begins, call upon the agents to produce any relevant document or to supply any relevant explanation. Formal note shall be 
taken of any refusal to produce documents or supply an explanation requested by it.

\section{Article 30: ENQUIRIES}

The Court may, at any time, entrust any individual, body, bureau, commission, or other organisation that it may select, and accepted by the parties to the dispute, with the task of carrying out an enquiry or giving an expert opinion.

\section{Article 31: REFUSAL OF EVIDENCE}

After the Court has received the proofs and evidence within the time specified for the purpose, it may, unless it decides that the interests of justice so require, refuse to accept any further oral or written evidence that any party may desire to present.

\section{Article 32: DEFAULT JUDGMENTS}

1. Whenever one of the parties does not appear before the Court, or fails to defend the case against it, the other party may call upon the Court to give its judgment.

2. The Court must before doing so, satisfy itself, not only that it has jurisdiction in accordance with Article 19, but also that the claim is well founded in fact and in law and that the other party had due notice.

3. An objection by the party concerned may be lodged against the judgment within ninety (90) days of it being notified of the default judgment. The objection shall not have the effect of staying the enforcement of the judgment by default

\section{Article 33: CONSIDERATION OF THE JUDGMENT}

1. When, subject to the control of the Court, the agent, counsel and advocates have completed their submissions of the case, the President shall declare the hearing closed.

2. The Court shall adjourn to consider its judgment.

3. The deliberations of the Court shall take place in private and shall remain secret at all times.

\section{Article 34: MAJORITY NECESSARY FOR DECISION}

1. All questions shall be decided by a majority of the Judges present.

2. In the event of equality of votes, the presiding Judge shall have a casting vote.

\section{Article 35: JUDGMENT}

1. The judgment shall state the reasons on which it is based. 
2. The judgment shall state the names of Judges who have taken part in the decision.

3. The judgment shall be signed by all the Judges and certified by the President and the Registrar. It shall be read in open session, due notice having been given to the agents.

4. Subject to Article 32 and 41 of this Protocol, the judgment shall be final.

\section{Article 36: SEPARATE OR DISSENTING OPINION}

If the judgment does not represent in whole or in part the unanimous opinion of the Judges, any Judge shall be entitled to deliver a separate or dissenting opinion.

\section{Article 37: BINDING FORCE OF JUDGMENTS}

The judgments of the Court shall be binding on the parties and in respect of that particular case.

\section{Article 38: DECISIONS ON INTERPRETATION AND APPLICATION OF THE} ACT

1. Decisions of the Court on the interpretation and application of the Act shall be binding on Member States and organs of the Union notwithstanding the provisions of Article 37 of this Protocol.

2. Whenever questions of interpretation of the Act arise in a case in which States other than those concerned have expressed an interest, the Registrar shall notify all such States and organs of the Union forthwith.

3. Every Member State and organ of the Union so notified has the right to intervene in the proceedings.

4. Any decision taken in application of Articles 38 and 39 of this Protocol shall be by a qualified majority of at least two (2) votes and in the presence of at least nine (9) Judges.

\section{Article 39: INTERPRETATION OF OTHER TREATIES}

1. Whenever the question of interpretation of a treaty arises in a case in which States other than those concerned have expressed an interest, the Registrar shall notify all such States and organs of the Union forthwith.

2. Every State Party and organ of the Union so notified has the right to intervene in the proceedings and the interpretation given by the judgment will be equally binding upon it.

\section{Article 40: INTERPRETATION OF A JUDGEMENT}

In the event of any dispute as to the meaning or scope of the judgment, the Court shall construe it upon the request of any of the parties. 


\section{Article 41: REVISION}

1. An application for revision of a judgment may be made only when it is based upon discovery of a new fact of such nature as to be a decisive factor, which fact was, when the judgment was given, unknown to the Court and also to the party claiming revision, provided that such ignorance was not due to negligence.

2. The proceedings for revision shall be opened by a ruling of the Court expressly recording the existence of the new fact, recognizing that it has such a character as to lay the case open to revision, and declaring the revision admissible on this ground.

3. The Court may require prior compliance with the terms of the judgment before it admits proceedings in revision.

4. The application for revision shall be made within six (6) months of the discovery of the new fact.

5. No application may be made after the lapse of ten (10) years from the date of the judgment.

\section{Article 42: INTERVENTION}

1. Any Member State that has an interest of a legal nature, which may be affected by the decision in the case, may submit a request to the Court to be permitted to intervene.

2. The Court shall decide upon the request.

\section{Article 43: COSTS}

Unless otherwise decided by the Court, each party shall bear its own costs.

\section{Article 44: ADVISORY OPINION}

1. The Court may give an advisory opinion on any legal question at the request of the Assembly, the Parliament, the Executive Council, the Peace and Security Council, the ECOSOCC, any of the Financial Institutions, a Regional Economic Community or such other organs of the Union as may be authorized by the Assembly.

2. A request for an advisory opinion under paragraph 1 of this Article shall be in writing and shall contain an exact statement of the question upon which the opinion is required and shall be accompanied by all relevant documents.

\section{CHAPTER V}

\section{Article 45: PROCEDURE FOR AMENDMENTS}

1. This Protocol may be amended if a State Party makes a written request to that effect to the Chairperson of the Assembly. 
2. Proposals for amendment shall be submitted to the Chairperson of the Commission who shall transmit same to Member States within thirty (30) days of receipt thereof.

3. The Assembly may adopt by a simple majority, the draft amendment after the Court has given its opinion on the amendment.

\section{Article 46: POWER OF THE COURT TO PROPOSE AMENDMENTS}

The Court shall have the power to propose such amendments to this Protocol as it may deem necessary to the Assembly through written communication to the Chairperson of the Commission for consideration in conformity with Article 45 of this Protocol.

\section{CHAPTER VI}

\section{Article 47: SEAT AND SEAL OF THE COURT}

1. The seat of the Court shall be determined by the Assembly from among States Parties. However, the Court may sit in any other Member State if circumstances warrant and with the consent of the Member State concerned. The seat of the Court may be changed by the Assembly after due consultations with the Court.

2. The Court shall have a seal bearing the inscription "The Court of Justice of the African Union".

\section{CHAPTER VII}

\section{Article 48: APPOINTMENT OF REGISTRAR}

1. The Court shall appoint the Registrar and Deputy Registrar(s) from amongst candidates proposed by the Judges of the Court, as it considers necessary, in accordance with the Rules of Court.

2. The Registrar and Deputy Registrar(s) shall be elected for a term of four (4) years. They may be re -appointed once. They shall reside at the seat of the Court.

3. The salary and conditions of service of the Registrar and Deputy Registrar(s) shall be determined by the Assembly upon recommendation of the Court through the Executive Council.

\section{Article 49: APPOINTMENT AND TERMS OF SERVICE OF OTHER STAFF}

1. The Court shall employ such staff as may be required to enable the Court to perform its functions and who shall hold office in the service of the Court.

2. The salary and other allowances of the other staff of the Court shall be determined by the Assembly upon the recommendation of the Court through the Executive Council. 


\section{Article 50: OFFICIAL LANGUAGES OF THE COURT}

The official and working languages of the Court shall be those of the Union.

\section{CHAPTER VIII}

\section{Article 51: EXECUTION OF JUDGMENT}

The State Parties shall comply with the judgment in any dispute to which they are parties within the time stipulated by the Court and shall guarantee its execution.

\section{Article 52: NON-COMPLIANCE WITH JUDGMENT}

1. Where a party has failed to comply with a judgment, the Court may, upon application by either party, refer the matter to the Assembly, which may decide upon measures to be taken to give effect to the judgment.

2. The Assembly may impose sanctions under paragraph 2 of Article 23 of the Act.

\section{Article 53: REPORT TO THE ASSEMBLY}

The Court shall submit to each ordinary session of the Assembly, a report on its work during the previous year. The report shall specify, in particular, the cases in which a State has not complied with the Court's judgment.

\section{CHAPTER IX}

\section{Article 54: BUDGET}

1. The Court shall elaborate its draft annual budget and shall submit it to the Assembly through the Executive Council.

2. The budget of the Court shall be borne by the Member States.

\section{Article 55: SUMMARY PROCEDURE}

With a view to the speedy dispatch of business, the Court shall form annually a chamber composed of five (5) Judges, which, at the request of the parties, may hear and determine cases by summary procedure in accordance with the Rules of Court. In addition, two (2) Judges shall be selected from among themselves for the purpose of replacing Judges who find it impossible to sit.

\section{Article 56: SPECIAL CHAMBERS}

The Court may from time to time form one or more chambers, composed of three (3) or more Judges as the Court may determine, for dealing with particular categories of cases.

\section{Article 57: JUDGMENT GIVEN BY A CHAMBER}

A judgment given by any of the chambers provided for in Articles 55 and 56 of this Protocol shall be considered as rendered by the Court. 


\section{CHAPTER X}

\section{Article 58: RULES OF COURT}

The Court shall frame rules for carrying out its functions and generally for giving effect to this Protocol. In particular, it shall lay down rules of procedure in conformity with this Protocol.

\section{Article 59: SIGNATURE, RATIFICATION AND ACCESSION}

1. This Protocol shall be open to signature, ratification and accession by Member States in accordance with their respective constitutional procedures.

2. The instruments of ratification shall be deposited with the Chairperson of the Commission.

3. Any Member State acceding to this Protocol after its entry into force shall deposit the instrument of accession with the Chairperson of the Commission.

\section{Article 60: ENTRY INTO FORCE}

This Protocol shall enter into force thirty (30) days after the deposit of the instruments of ratification by fifteen (15) Member States. 